\title{
Microbial safety status of Serro artisanal cheese produced in Brazil
}

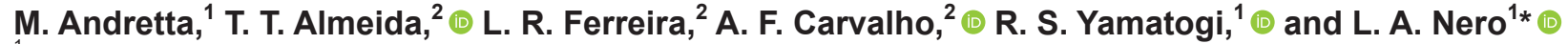 \\ ${ }^{1}$ Departamento de Veterinária, Universidade Federal de Viçosa, 36570-900, Viçosa, MG, Brazil \\ ${ }^{2}$ Departamento de Tecnologia de Alimentos, Universidade Federal de Viçosa, 36570-900, Viçosa, MG, Brazil
}

\section{ABSTRACT}

Considering the growing consumption of artisanal foods worldwide, we aimed to evaluate the microbial safety of Serro artisanal cheese (SAC), produced in Minas Gerais State, Brazil. This cheese is produced with raw milk using 1 of 2 natural starter cultures: "pingo" and "rala." A total of 53 SAC samples (pingo $=8$; rala $=45$ ) were obtained from different farmers and subjected to conventional and molecular assays to detect and enumerate Listeria monocytogenes, Salmonella spp., coagulase-positive staphylococci (CPS), diarrheagenic Escherichia coli, Mycobacterium tuberculosis, and Brucella abortus. The SAC samples were also subjected to an ELISA to detect classical staphylococcal enterotoxins (CSE: SEA, SEB, SEC, SED, SEE) and to PCR assays to detect staphylococcal enterotoxin-related genes (sea, seb, sec, sed, see). Coagulase-positive staphylococci isolates were obtained and tested by the same assays to detect their potential in CSE production and presence of CSE-related genes. None of the SAC samples showed any of the screened food-borne pathogens and zoonotic agents, and none showed the presence of CSE by phenotypic and genotypic approaches. Despite the absence of microbial hazards, mean counts of CPS in SAC samples were $5.2 \mathrm{log}$ $\mathrm{cfu} / \mathrm{g}$ (pingo starter) and $4.6 \mathrm{log} \mathrm{cfu} / \mathrm{g}$ (rala starter), indicating poor hygiene practices during production. None of the tested CPS isolates $(\mathrm{n}=116)$ produced CSE or presented CSE-related genes. Despite the relative microbial safety, hygienic conditions during SAC production must be improved to meet official guidelines established in Brazil.

Key words: artisanal cheese, Serro, hazard, good manufacturing practices, Staphylococcus

\section{INTRODUCTION}

The consumption of artisanal cheeses is increasing worldwide because of consumer demand for natural

Received May 15, 2019.

Accepted July 24, 2019.

*Corresponding author: nero@ufv.br foods without chemical additives, and because of valorization of cultural and historical aspects of different countries (Claeys et al., 2013). The cheeses produced in Minas Gerais state represent one of the oldest and most traditional artisanal products made in Brazil, and they are named according to their region of origin; for example, Serro, Salitre, Campos das Vertentes, Canastra, Araxá, and Triângulo (EMATER, 2019). The production of these artisanal cheeses has socioeconomic relevance for the dairy farmers, leading to official support from the Minas Gerais state government that established specific guidelines for production in 2002, including the health of the producing animals, hygiene during production, and microbiological parameters for quality and safety of end products (Minas Gerais, 2002a,b). Minas artisanal cheeses have been recognized as a Brazilian Historical Patrimony (IPHAN, 2006), and artisanal cheeses produced in the Serro region (Figure 1) received an indication of Geographic Origin Denomination (INPI, 2011), improving their value in retail sales.

Serro artisanal cheese (SAC) is traditionally produced with raw milk and a natural starter culture called "pingo," which is obtained from SAC whey produced after molding. Then, SAC is subjected to ripening for 17 to $22 \mathrm{~d}$, resulting in a semi-hard cheese with a compact texture, white to yellowish, salty, and characterized by floral notes and a spicy flavor (INPI, 2011). Since the 1990s, the pingo starter has been replaced by an alternative starter culture, named "rala," which is the grated cheese resulting from the SAC cleaning, after ripening; this procedure is supposed to ensure a low microbial contamination in SAC (personal communication, Cooperativa dos Produtores Rurais do Serro CooperSerro, Serro, MG, Brazil). Although SAC is well accepted by consumers, few scientific studies have assessed its quality and safety or the differences between "pingo" and "rala" starters. It is generally accepted that SAC production lacks standardization, resulting in poor hygienic quality of the end products (Brant et al., 2007; Vale et al., 2018).

Thus, proper scientific studies are needed to assess the microbiological characteristics of $\mathrm{SAC}$ in order to generate reliable data that can support enhanced 

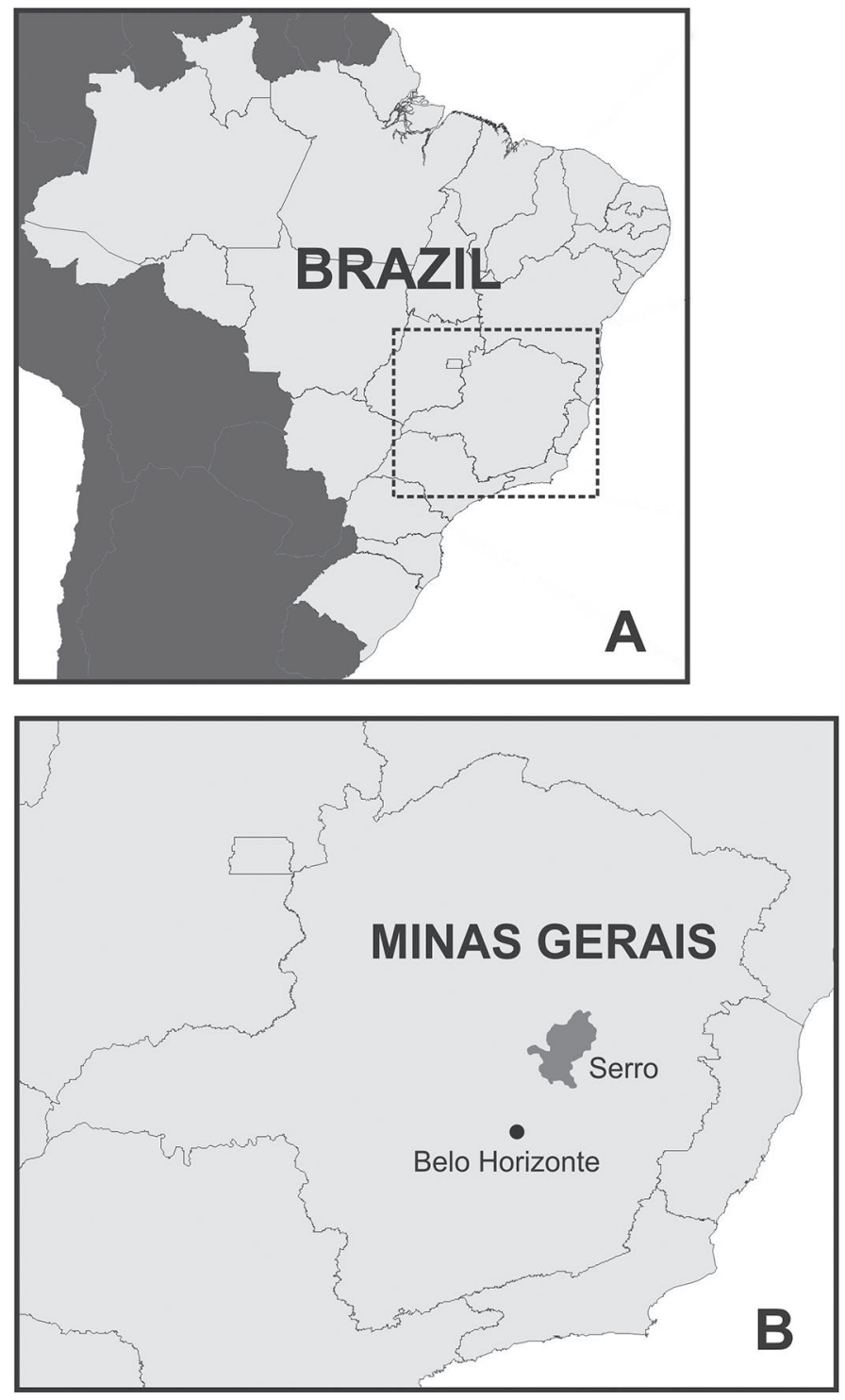

Figure 1. Localization of Minas Gerais state in Brazil (A) and the Serro region in Minas Gerais (capital: Belo Horizonte) (B; dotted area in A).

SAC quality and safety. As SAC is produced with raw milk, it is susceptible to contamination by pathogenic bacteria that pose hazards and risks to human health (Gould et al., 2014). A variety of food-borne pathogens associated with artisanal foods present hazards, such as Listeria monocytogenes, Salmonella spp., Campylobacter spp., pathogenic Escherichia coli, enterotoxins produced by Staphylococcus spp., and microorganisms with zoonotic potential, such as Brucella abortus and Mycobacterium spp. All of these are commonly associated with consumption of raw milk cheeses (Claeys et al., 2013). For these reasons, in the present study, we aimed to assess the microbial safety of SAC.

\section{MATERIALS AND METHODS}

\section{Samples and Dilutions}

Serro artisanal cheese samples $(\mathrm{n}=53)$ from different farmers were obtained from the distribution center of the SAC Producers Association (CooperSerro, Belo Horizonte, MG, Brazil) and kept under refrigeration pending microbiological analysis. Portions of $25 \mathrm{~g}$ of each sample were aseptically obtained, transferred to sterile bags with $225 \mathrm{~mL}$ of citrate solution $(0.85 \%$, wt/vol), and diluted 10-fold in $\mathrm{NaCl} 0.85 \%$ (wt/vol). The total DNA from SAC samples was obtained by using the PureLink Microbiome DNA Purification Kit (Invitrogen, ThermoFisher Scientific, Waltham, MA) and subjected to PCR. The SAC samples were categorized based on their production procedures, depending on whether the pingo $(\mathrm{n}=8)$ or rala $(\mathrm{n}=45)$ starter was used.

\section{Listeria monocytogenes}

Listeria monocytogenes was assayed based on Wehr and Frank (2004). Portions of $25 \mathrm{~g}$ of each sample were transferred to sterile bags, with $225 \mathrm{~mL}$ of Listeria Enrichment Broth (Oxoid Ltd., Basingstoke, UK) and incubated at $30^{\circ} \mathrm{C}$ for $48 \mathrm{~h}$. Then, the obtained cultures were streaked onto plates containing Palcam and Oxford agars (Oxoid Ltd.) and incubated at $35^{\circ} \mathrm{C}$ for $48 \mathrm{~h}$. Colonies that presented typical Listeria morphology (small, black, and surrounded by black halos) were purified on trypticase soy agar (Oxoid), subjected to DNA extraction (Wizard Genomic DNA Purification kit, Promega Corp., Madison, WI) and PCR assays targeting prs for Listeria spp., and hly for L. monocytogenes (Hudson et al., 2001; Doumith et al., 2004). The total DNA obtained from SAC samples was subjected to the same PCR assay targeting hly for detection of L. monocytogenes (Hudson et al., 2001). Primers, product sizes, PCR conditions, and positive controls are detailed in Table 1. Based on the obtained results, the presence or absence of $L$. monocytogenes was expressed per $25 \mathrm{~g}$ of SAC.

\section{Salmonella spp.}

The presence of Salmonella spp. was assessed based on the protocol described in ISO 6579 (ISO, 2017). Portions of $25 \mathrm{~g}$ of each SAC samples were transferred to sterile bags with $225 \mathrm{~mL}$ of buffered peptone water (Oxoid Ltd.) and incubated at $35^{\circ} \mathrm{C}$ for $18 \mathrm{~h}$. Then, aliquots of the obtained cultures were transferred to Rappaport-Vassiliadis (Oxoid Ltd.) and Muller Kauffmann tetrathionate (Oxoid Ltd.) broth, followed by 


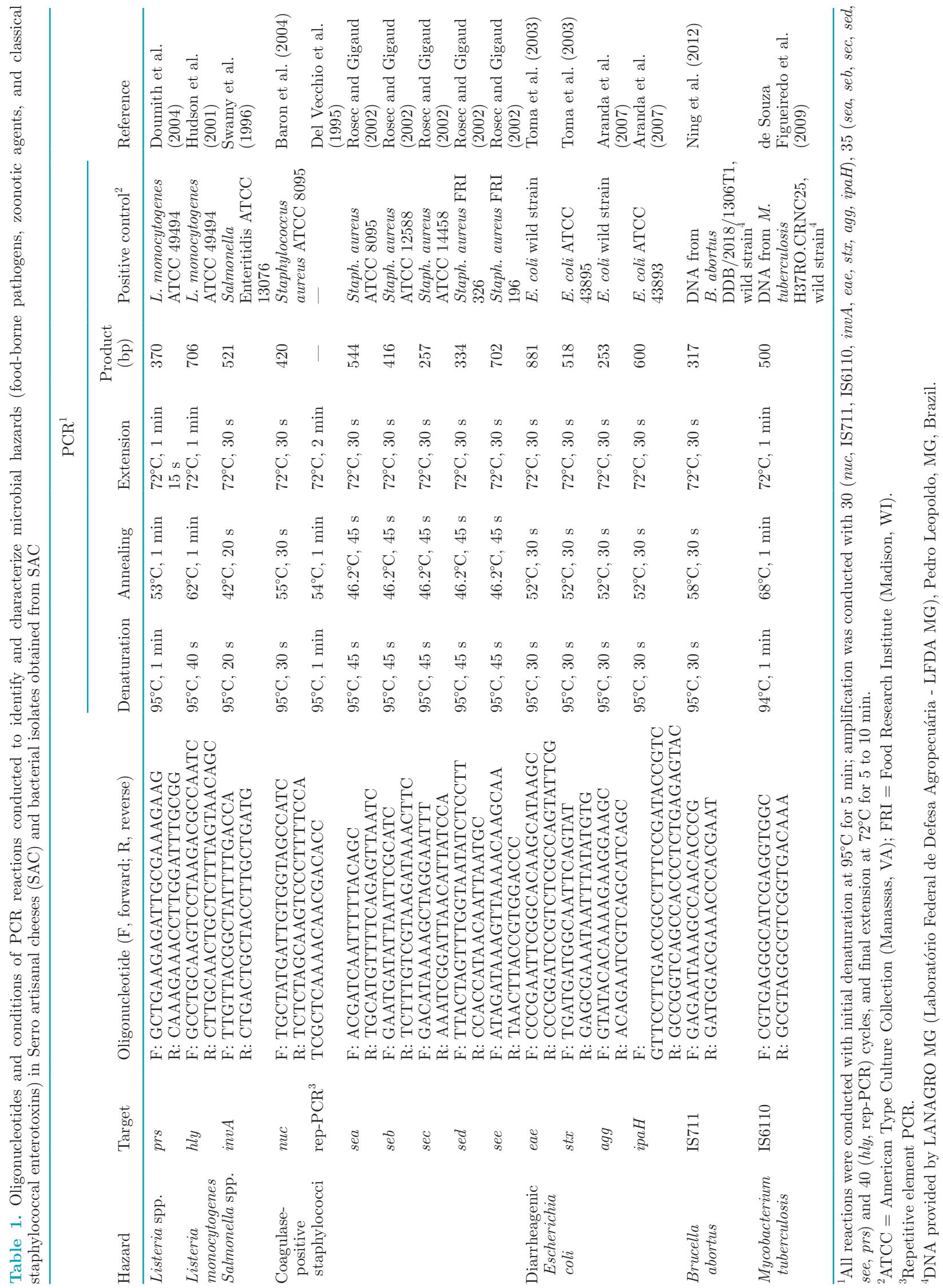


incubation at $41^{\circ} \mathrm{C}$ and $35^{\circ} \mathrm{C}$, respectively, for $24 \mathrm{~h}$. The obtained cultures were then streaked onto plates containing mannitol lysine crystal violet brilliant green agar (MLCB; Oxoid Ltd.) and xylose lysine deoxycholate agar (XLD; Oxoid Ltd.) and incubated at $35^{\circ} \mathrm{C}$ for $24 \mathrm{~h}$. Colonies that presented typical Salmonella morphologies (MLCB: dark gray, rounded; XLD: black centered, rounded) were purified on TSA (Oxoid Ltd.), subjected to DNA extraction (Wizard Genomic DNA Purification kit, Promega), and then to a PCR assay targeting invA (Swamy et al., 1996). Total DNA from SAC samples was subjected to the same PCR protocol targeting invA for Salmonella spp. detection (Swamy et al., 1996). Primers, product sizes, PCR conditions, and positive controls are detailed in Table 1 . Based on the obtained results, the presence or absence of Salmonella was expressed per $25 \mathrm{~g}$ of SAC.

\section{Coagulase-Positive Staphylococci and Classical Staphylococcal Enterotoxins}

Selected dilutions of SAC samples were surface plated onto Baird Parker agar plates (Oxoid Ltd.), according to ISO 6888-1 (ISO, 1999). Plates were incubated at $35^{\circ} \mathrm{C}$ for $48 \mathrm{~h}$, when colonies were analyzed by their morphology (typical: circular, smooth, convex, gray to jet-black, with a light-colored margin surrounded by 2 halos, and atypical), enumerated, and selected for additional characterization. The selected colonies were subjected to Gram staining and tested for production of catalase, coagulase, and DNase (ISO, 1999). Isolates with biochemical characteristics consistent with coagulase-positive staphylococci (CPS) were subjected to DNA extraction (as described above) and a PCR assay targeting nuc, according Baron et al. (2004), for Staph. aureus identification. Primers, product sizes, PCR conditions, and positive controls are detailed in Table 1. Based on the obtained results, counts of CPS were obtained and expressed as colony-forming units per $\mathrm{g}(\mathrm{cfu} / \mathrm{g})$ of SAC.

Aliquots of SAC samples (10 g) were subjected to an ELISA to detect the presence of classical staphylococcal enterotoxins (CSE; SEA, SEB, SEC, SED, and SEE), by using the Ridascreen Set Kit SEA-SEE (R-Biopharm, Darmstadt, Germany). Based on the obtained results, the presence or absence of CSA was expressed per $10 \mathrm{~g}$ of SAC.

The DNA from isolates carrying the nuc gene was subjected to a repetitive element (rep)-PCR protocol using the single primer RW3A (Del Vecchio et al., 1995). Primers and PCR conditions are detailed in Table 1. The obtained genetic profiles were analyzed by using the Bionumerics 6.6 software (Applied Maths, Gand, Belgium), considering Dice coefficient and unweighted pair group method with arithmetic mean (UPGMA) method (optimization/tolerance of $5 \%$ and similarity index of 100\%). Based on their genetic profiles and origin (SAC sample and starter culture), isolates were selected, transferred to brain heart infusion agar (Oxoid), incubated at $35^{\circ} \mathrm{C}$ for $24 \mathrm{~h}$, and centrifuged at $3,500 \times$ $g$ at $10^{\circ} \mathrm{C}$. Then, the supernatant was subjected to the same ELISA protocol (Ridascreen Set Kit SEA-SEE, R-Biopharm) to detect production of CSE. Based on the obtained results, Staph. aureus isolates were categorized as enterotoxin producers or not.

The DNA from the selected Staph. aureus isolates and from the SAC samples was subjected to PCR assays targeting genes related to production of SEA (sea), SEB (seb), SEC (sec), SED (sed), and SEE (see), as described by Rosec and Gigaud (2002). DNA from SAC samples was additionally subjected to the PCR assay described above for nuc (Baron et al., 2004), as a control for the presence of Staph. aureus. Based on the obtained results, Staph. aureus isolates and SAC were categorized as having, or not, the potential to produce CSE.

\section{Molecular Detection of Diarrheagenic E. coli, B. abortus, and M. tuberculosis}

The total DNA from SAC samples was subjected to a multiplex PCR assay to identify the potential presence of the 4 groups of diarrheagenic E. coli: (1) enteropathogenic E. coli (EPEC), targeting the gene eae; (2) Shiga-toxin producing E. coli (STEC), targeting stx; (3) enteroaggregative $E$. coli (EAEC), targeting agg; and (4) enteroinvasive E. coli (EIEC), targeting ipaH (Toma et al., 2003; Aranda et al., 2007). Also, total DNA from SAC was subjected to PCR assays to identify the potential presence of (1) B. abortus targeting the IS711 genome region, as described by Ning et al. (2012), and (2) M. tuberculosis, targeting the IS6110 genomic region, as described by de Souza Figueiredo et al. (2009). Primers, product sizes, PCR conditions, and positive controls are detailed in Table 1 . Based on the obtained results, the potential presence or absence of the target pathogens was expressed per SAC.

\section{Data Analysis}

The SAC samples were categorized based on the presence or absence of the target pathogens, as described above. Counts of CPS were converted to $\log _{10}$ and compared considering SAC production (pingo and rala) by ANOVA $(P<0.05)$; SAC with CPS counts $<100 \mathrm{cfu} / \mathrm{g}$ were not considered in this analysis. Also, SAC samples were categorized based on their CPS counts and recorded frequencies compared by $\chi^{2}(P<0.05)$ considering 
Table 2. Frequencies of Serro artisanal cheese (SAC) samples produced with "pingo" and "rala" starters with different contamination levels by coagulase-positive staphylococci (CPS)

\begin{tabular}{llccc}
\hline & & \multicolumn{2}{c}{ SAC } & \\
\cline { 3 - 4 } Category $^{1}$ & Count $(\mathrm{cfu} / \mathrm{g})$ & Pingo & Rala & \multirow{2}{*}{$P$-value $^{2}$} \\
\hline Contamination level & $<100$ & 3 & 9 & 0.576 \\
& 100 to 1,000 & 0 & 1 & 1.000 \\
& 1,000 to 10,000 & 0 & 6 & 0.239 \\
Minas Gerais (2002a) & 10,000 to 100,000 & 3 & 17 & 0.749 \\
European Union (2005) & $>100,000$ & 5 & 35 & 0.850 \\
\hline & $>1,000$ & 3 & 12 & 0.664 \\
\hline
\end{tabular}

${ }^{1}$ Contamination levels of CPS in all SAC samples, and considering upper limits of CPS in raw milk cheeses established in Minas Gerais (2002a) and European Union (2005).

${ }^{2} P$-values $>0.05$ indicate absence of significant differences by $\chi^{2}$ test.

SAC production (pingo and rala) and reference values for raw milk cheeses in Minas Gerais State (upper limit $=1,000 \mathrm{cfu} / \mathrm{g}$; Minas Gerais, 2002a) and the European Union (upper limit $=100,000 \mathrm{cfu} / \mathrm{g}$; European Union, 2005). Statistical analysis was conducted by using the software XLStat 19.01 (AddinSoft, New York, NY).

\section{RESULTS}

The results for the pathogenic bacteria assessed by conventional and molecular methods in each SAC sample are presented in Supplemental Table S1 (https: //doi.org/10.3168/jds.2019-16967). Considering the results obtained by conventional methods, none of the SAC samples showed L. monocytogenes or Salmonella spp.; Listeria spp. presumptive colonies were obtained from just one SAC sample, and they were positive only for prs (negative for hly), allowing their identification only to the genus level. In agreement, none of the SAC samples were positive for L. monocytogenes or Salmonella spp. by PCR. In addition, no SAC sample had PCR amplification products for diarrheagenic E. coli, B. abortus, or M. tuberculosis.

The mean CPS count in pingo SAC was $5.2 \mathrm{log}$ $\mathrm{cfu} / \mathrm{g}$ (SE: 0.3 ) and in rala SAC was $4.6 \mathrm{cfu} / \mathrm{g}$ (SE: $0.1)$; these counts did not differ $(P=0.139)$. The frequencies of SAC samples with different levels of contamination by CPS are presented in Table 2. Based on these results, SAC samples showed high levels of contamination by CPS, but no statistical difference was detected among the SAC produced with pingo and rala (see mean counts, Table 2). Based on the reference values established in Minas Gerais for CPS counts in artisanal cheeses (Minas Gerais, 2002a), 40 (75.5\%) SAC samples would not be considered suitable for retail sale because of counts $>10^{3} \mathrm{cfu} / \mathrm{g}$; of these, $5(62.5 \%)$ were produced using pingo and $35(77.8 \%)$ using rala $(P=0.664$, Table 2). Similarly, based on the European Union reference value of $10^{5} \mathrm{cfu} / \mathrm{g}$ of CPS in raw milk cheeses (European Union, 2005), 15 (28.3\%) SAC samples would not be adequate for human consumption, $3(37.5 \%)$ pingo SAC and $12(26.7 \%)$ rala $\mathrm{SAC}(P=$ $0.850)$. In addition, the same $15(28.3 \%)$ SAC samples would be subjected to further analysis for staphylococcal enterotoxins once they presented CPS counts $>10^{5}$ cfu/g (European Union, 2005).

Despite the high counts of CPS observed here, none of the SAC samples were positive for CSE assayed by conventional (ELISA) or molecular (PCR) methods. A total of 866 colonies were obtained from Baird-Parker plates, 155 being typical and 711 atypical. Of this total, 350 isolates were characterized as CPS and 427 as DNase-positive. A total of 316 of the CPS isolates were positive for nuc, being identified as Staph. aureus. Based on their genetic profiles obtained by rep-PCR and SAC origin, 116 isolates were selected for CSE assays: none showed positive results by ELISA or PCR. Supplemental Figure S1 (https://doi.org/10.3168/jds .2019-16967) shows the genetic profiles of the 116 isolates selected, based on rep-PCR.

\section{DISCUSSION}

The presence of food-borne pathogens and zoonotic agents in artisanal food produced with raw milk is a source of concern to producers, consumers, and official inspection services. Considering the widespread acceptance of artisanal food products by consumers, assessment of their safety is mandatory, through proper inspection of producer farms and establishment of adequate guidelines for production, thus assuring the safety to consumers. Contamination by pathogenic bacteria can occur at different stages of artisanal cheese production, starting with the raw milk obtained from potentially infected animals and from the milking and producing environment (Melo et al., 2015). Listeria monocytogenes and Salmonella spp. are food-borne pathogens usually associated with raw milk and dairy 
products, and they are commonly screened in dairy products as safety indicators (Torres-Vitela et al., 2012; Almeida et al., 2013). None of the SAC samples included in this study were positive for these pathogens, by conventional or molecular methods, as also observed in previous studies with raw milk cheeses (Esho et al., 2013; Amorim et al., 2014; Martins et al., 2015; Dias et al., 2016; Soares et al., 2018).

Escherichia coli is an important indicator to assess risk and hygiene failures in the cheese production system, because it is present in the gastrointestinal tract of humans and healthy animals and consequently can be present in the milk production environment (Cardoso and Marin, 2017). Some strains can be pathogenic and cause foodborne illness in humans and animals. Among these, the 6 most important categories of pathogenic $E$. coli vary in infective and toxin-producing mechanisms: STEC, EPEC, enterotoxigenic E. coli, EAEC, EIEC, and diffusely adherent E. coli (Farrokh et al., 2013). In this study, none of the SAC samples were positive for any category of pathogenic E. coli. In contrast, some studies have found diarrheagenic E. coli in samples of artisanal cheeses (Paneto et al., 2007; Marozzi et al., 2016; de Campos et al., 2018; Parussolo et al., 2019), but all have made an association between the microbiological culture and the use of the PCR technique, suggesting that the food matrix may interfere in the direct detection of these pathogenic strains.

Considering the concern surrounding $M$. tuberculosis and $B$. abortus as zoonotic agents, as direct transmission from animals to humans may occur, the ingestion of dairy products contaminated with these bacteria is considered the greatest risk to human health: the World Organization for Animal Health (OIE) and the Food and Agriculture Organization of the United Nations (FAO) consider brucellosis to be the world's most neglected zoonosis (Dadar et al., 2019). Because of this, the Brazilian Ministry of Agriculture started a national program in 2001 to control and eradicate animal brucellosis and tuberculosis, focusing mainly on cattle (dairy and beef); as a consequence, all current Brazilian legislation related to dairy production, including raw milk and artisanal cheeses, is included in the program, ensuring the proper control of these diseases in producing animals (Minas Gerais, 2002b; Brasil, 2017). As expected, no SAC samples were positive for B. abortus or M. tuberculosis by PCR. Few studies have been conducted on the presence of these zoonotic agents based on PCR assays in artisanal cheeses, but they have been found in this matrix using highly sensitive molecular assays, such as quantitative PCR and nested PCR (Ongör et al., 2006; Cezar et al., 2016; Silva et al., 2016, 2018).
The presence of Staphylococcus in SAC samples was expected, because isolates of this genus are usually found on the skin and mucous membranes of animals and humans as well as the surfaces of dairy equipment and the milking environment (Basanisi et al., 2016). Cheese production, in particular, is characterized by direct manipulation, increasing the potential of transferring of Staphylococcus spp. from utensils, equipment, and employees to the end products (Johnson, 2017). Because of these potential contamination routes, Staphylococcus spp. are usually considered good indicators of proper handling and good manufacturing practices during food processing (Novakovic and Grujic, 2017). The intrinsic conditions of the cheese, such as $\mathrm{pH}$, water activity, and $\mathrm{NaCl}$ concentrations, can favor the growth of Staphylococcus spp. (Viana et al., 2009; Borelli et al., 2011). Although controversial, the enterotoxigenic potential of Staphylococcus has always been associated with its pathogenic potential, which is usually characterized by its ability to produce the enzyme coagulase (Rodríguez et al., 2016). Therefore, official guidelines in Brazil and Europe consider counts of CPS as a reference for safety (Minas Gerais, 2002a; European Union, 2005). Thus, enumeration and characterization of Staphylococcus spp. is an important step to evaluate potential factors that may pose a risk to consumers and a reliable tool to support quality control programs, such as hazard analysis and critical control points (HACCP) and good manufacturing practices (GMP; Ding et al., 2016).

The high counts of CPS observed in the present study indicate hygienic failures in SAC production, in agreement with similar studies with artisanal cheeses (Brant et al., 2007; Dores et al., 2013; Amorim et al., 2014; Dias et al., 2016; Vinha et al., 2018). Information on the microbiological influence of the type of starter culture (pingo or rala) used for the production of SAC is scarce; in the current study, pingo SAC had higher CPS counts than rala SAC, albeit not significantly different. In addition, no significant differences were observed when contamination levels by CPS were considered according to SAC starter culture $(P>0.05$, Table 2$)$. These results indicate poor hygienic conditions during SAC production, independently of the starter culture used. To date, no study has addressed the influence of starter cultures (pingo or rala) on the microbiological characteristics of SAC.

The production of staphylococcal enterotoxins is one of the main virulence mechanisms of Staph. aureus, and 23 different enterotoxins have been identified so far; however, $95 \%$ of confirmed outbreaks are due to the classical enterotoxins (SEA, SEB, SEC, SED and SEE; Rahimi and Alian, 2013). Based on European legislation, only artisanal cheese batches that have samples 
with CPS counts $>10^{5} \mathrm{cfu} / \mathrm{g}$ must be assayed for the presence of CSE (European Union, 2005), as observed in some studies (Pelisser et al., 2009; Ciupescu et al., 2018). In Brazil, no current legislation addresses the evaluation of CSE in artisanal cheeses (Brasil, 2001; Minas Gerais, 2002a). Even though the SAC samples had relatively high counts of CPS, none were positive for the presence of the CSE assayed by ELISA, indicating that the SAC samples did not pose a direct risk to consumers related to CSE (Johler et al., 2015; Rola et al., 2016).

Despite the absence of CSE in SAC samples, it is necessary to study Staph. aureus with enterotoxigenic potential, because the genes encoding different enterotoxins are transported and disseminated by different genetic elements and can be expressed according to the intrinsic and extrinsic conditions of the food, such as temperature, $\mathrm{pH}$, water activity, and salt concentration (Denayer et al., 2017). In this study, none of the SAC samples showed amplification by PCR of sea, seb, sec, sed, or see, as also observed previously in similar studies (Martins et al., 2014; Johler et al., 2015). In addition, none of the Staph. aureus isolated in this study were positive for the screened CSE genes or showed CSE production by ELISA. Safety related to CSE in Staphylococcus stains must be assessed by phenotypic and genotypic approaches to detect potential CSE producers that express this characteristic under specific conditions and might transfer these genetic elements to non-CSEproducing strains. The identification of Staphylococcus strains from artisanal cheeses that present CSE-related genes despite not being CSE producers is not uncommon (Carfora et al., 2015; Grispoldi et al., 2019). However, the CSE results of Staph. aureus isolates obtained in the present study might indicate a particular profile in the regional staphylococcal microbiota, leading to further studies to investigate their genetic profiles and other CSE-related genes and production.

\section{CONCLUSIONS}

The absence of Staphylococcus with potential to produce CSE and the absence of pathogens such as Salmonella, L. monocytogenes, diarrheagenic E. coli, M. tuberculosis, and B. abortus, indicate that $\mathrm{SAC}$ is relatively safe, not posing a risk for transferring foodborne pathogens and zoonotic agents to consumers. However, the high CPS counts indicated poor hygiene conditions during processing of SAC with different natural starter cultures ("pingo" and "rala"), demanding proper control of processing and establishment of quality and production parameters, in order to standardize production and ensure a high-quality end product.

\section{ACKNOWLEDGMENTS}

The authors thank Conselho Nacional de Desenvolvimento Científico e Tecnológico (CNPq, Brasília, DF, Brazil), Coordenação de Aperfeiçoamento de Pessoal de Nível Superior (CAPES, Brasília, DF, Brazil - financial code 001), and Fundação de Amparo à Pesquisa do Estado de Minas Gerais (FAPEMIG, Belo Horizonte, MG, Brazil) for financial support, Laboratório Federal de Defesa Agropecuária MG (LFDA - LANAGRO MG, Pedro Leopoldo, MG, Brazil) for providing DNA of the positive controls for B. abortus and $M$. tuberculosis, and Cooperativa dos Produtores Rurais do Serro (CooperSerro, Serro, MG, Brazil) for agreeing to participate in this study.

\section{REFERENCES}

Almeida, G., R. Magalhães, L. Carneiro, I. Santos, J. Silva, V. Ferreira, T. Hogg, and P. Teixeira. 2013. Foci of contamination of Listeria monocytogenes in different cheese processing plants. Int. J. Food Microbiol. 167:303-309.

Amorim, A. L. B. C., E. P. Couto, A. P. Santana, J. L. Ribeiro, and M. A. Ferreira. 2014. Avaliação da qualidade microbiológica de queijos do tipo Minas padrão de produção industrial, artesanal e informal. Rev. Inst. Adolfo Lutz 73:364-367.

Aranda, K. R. S., S. H. Fabbricotti, U. Fagundes-Neto, and I. C. A. Scaletsky. 2007. Single multiplex assay to identify simultaneously enteropathogenic, enteroaggregative, enterotoxigenic, enteroinvasive and Shiga toxin-producing Escherichia coli strains in Brazilian children. FEMS Microbiol. Lett. 267:145-150.

Baron, F., M.-F. Cochet, J.-L. Pellerin, N. B. Zakour, A. Lebon, A. Navarro, I. Proudy, Y. Le Loir, and M. Gautier. 2004. Development of a PCR test to differentiate between Staphylococcus aureus and Staphylococcus intermedius. J. Food Prot. 67:2302-2305.

Basanisi, M. G., G. Nobili, G. La Bella, R. Russo, G. Spano, G. Normanno, and G. La Salandra. 2016. Molecular characterization of Staphylococcus aureus isolated from sheep and goat cheeses in southern Italy. Small Rumin. Res. 135:17-19.

Borelli, B. M., I. C. A. Lacerda, L. R. Brandão, C. R. Vianna, M. C. Ferreira, F. C. O. Gomes, L. S. Carmo, L. G. D. Heneine, and C. A. Rosa. 2011. Identification of Staphylococcus spp. isolated during the ripening process of a traditional minas cheese. Arq. Bras. Med. Vet. Zootec. 63:481-487

Brant, L. M. F., L. M. Fonseca, and M. C. C. Silva. 2007. Avaliação da qualidade microbiológica do queijo-de-minas artesanal do SerroMG. Arq. Bras. Med. Vet. Zootec. 59:1570-1574.

Brasil. 2001. Ministério da Saúde. Regulamento Técnico sobre Padrões Microbiológicos para Alimentos. in RDC-12. ANVISA, Brasília, DF

Brasil. 2017. Ministério da Agricultura, Pecuária e Abastecimento. 2017. Regulamento Técnico do Programa Nacional de Controle e Erradicação da Brucelose e da Tuberculose Animal - PNCEBT e Classificação das Unidades da Federação de acordo com o grau de risco para as doenças brucelose e tuberculose. Instrução Normativa n. 10, 2017 March 03. MAPA, Brasília, DF, Brazil.

Cardoso, P., and J. M. Marin. 2017. Occurrence of non-O157 Shiga toxin-encoding Escherichia coli in artisanal mozzarella cheese in Brazil: Risk factor associated with food workers. Food Sci. Technol. (Campinas) 37:41-44.

Carfora, V., A. Caprioli, N. Marri, D. Sagrafoli, C. Boselli, G. Giacinti, G. Giangolini, L. Sorbara, S. Dottarelli, A. Battisti, and S. Amatiste. 2015. Enterotoxin genes, enterotoxin production, and methicillin resistance in Staphylococcus aureus isolated from milk and dairy products in Central Italy. Int. Dairy J. 42:12-15. 
Cezar, R. D. S., N. Lucena-Silva, J. M. Borges, V. L. A. Santana, and J. W. Pinheiro Jr.. 2016. Detection of Mycobacterium bovis in artisanal cheese in the state of Pernambuco, Brazil. Int. J. Mycobacteriol. 5:269-272.

Ciupescu, L.-M., F. Auvray, I. M. Nicorescu, T. Meheut, V. Ciupescu, A.-L. Lardeux, R. Tanasuica, and J.-A. Hennekinne. 2018. Characterization of Staphylococcus aureus strains and evidence for the involvement of non-classical enterotoxin genes in food poisoning outbreaks. FEMS Microbiol. Lett. 365:fny139. https://doi.org/10 $.1093 /$ femsle/fny139.

Claeys, W. L., S. Cardoen, G. Daube, J. De Block, K. Dewettinck, K. Dierick, L. De Zutter, A. Huyghebaert, H. Imberechts, P. Thiange, Y. Vandenplas, and L. Herman. 2013. Raw or heated cow milk consumption: Review of risks and benefits. Food Control 31:251-262.

Dadar, M., Y. Shahali, and A. M. Whatmore. 2019. Human brucellosis caused by raw dairy products: A review on the occurrence, major risk factors and prevention. Int. J. Food Microbiol. 292:39-47.

de Campos, A. C. L. P., J. J. Puño-Sarmiento, L. P. Medeiros, L. E. S. Gazal, R. P. Maluta, A. Navarro, R. K. T. Kobayashi, E. P. Fagan, and G. Nakazato. 2018. Virulence genes and antimicrobial resistance in Escherichia coli from cheese made from unpasteurized milk in Brazil. Foodborne Pathog. Dis. 15:94-100.

de Souza Figueiredo, E. E., F. G. Silvestre, W. N. Campos, L. V. Furlanetto, L. Medeiros, W. Lilenbaum, L. S. Fonseca, J. T. Silva, and V. M. F. Paschoalin. 2009. Identification of Mycobacterium bovis isolates by a multiplex PCR. Braz. J. Microbiol. 40:231-233.

Del Vecchio, V. G., J. M. Petroziello, M. J. Gress, F. K. McCleskey, G. P. Melcher, H. K. Crouch, and J. R. Lupski. 1995. Molecular genotyping of methicillin-resistant Staphylococcus aureus via fluorophore-enhanced repetitive-sequence PCR. J. Clin. Microbiol. 33:2141-2144.

Denayer, S., L. Delbrassinne, Y. Nia, and N. Botteldoorn. 2017. Foodborne outbreak investigation and molecular typing: High diversity of Staphylococcus aureus strains and importance of toxin detection. Toxins (Basel) 9:407.

Dias, B. F., S. M. Ferreira, V. S. Carvalho, and D. S. B. Soares. 2016 Qualidade microbiológica e físico-química de queijo minas frescal artesanal e industrial. J. Neotrop. Agric. 3:57-64.

Ding, T., Y.-Y. Yu, D. W. Schaffner, S.-G. Chen, X.-Q. Ye, and D.-H. Liu. 2016. Farm to consumption risk assessment for Staphylococcus aureus and staphylococcal enterotoxins in fluid milk in China. Food Control 59:636-643.

Dores, M. T., R. S. Dias, E. F. Arcuri, J. E. Nobrega, and C. L. L. F. Ferreira. 2013. Enterotoxigenic potential of Staphylococcus aureus isolated from artisan Minas cheese from the Serra da Canastra MG, Brazil. Food Sci. Technol. (Campinas) 33:271-275.

Doumith, M., C. Buchrieser, P. Glaser, C. Jacquet, and P. Martin. 2004. Differentiation of the major Listeria monocytogenes serovars by multiplex PCR. J. Clin. Microbiol. 42:3819-3822.

EMATER. 2019. Queijo Minas Artesanal. Empresa de Assistência Técnica e Extensão Rural do Estado de Minas Gerais, Belo Horizonte, MG, Brazil.

Esho, F. K., B. Enkhtuya, A. Kusumoto, and K. Kawamoto. 2013 Microbial assessment and prevalence of foodborne pathogens in natural cheeses in Japan. BioMed Res. Int. 2013:205801.

European Union. 2005. Commission Regulation (EC) No 2073/2005 of 15 November 2005 on microbiological criteria for foodstuffs. Off. J. L338:301-326.

Farrokh, C., K. Jordan, F. Auvray, K. Glass, H. Oppegaard, S. Raynaud, D. Thevenot, R. Condron, K. De Reu, A. Govaris, K. Heggum, M. Heyndrickx, J. Hummerjohann, D. Lindsay, S. Miszczycha, S. Moussiegt, K. Verstraete, and O. Cerf. 2013. Review of Shiga-toxin-producing Escherichia coli (STEC) and their significance in dairy production. Int. J. Food Microbiol. 162:190-212.

Gould, L. H., E. Mungai, and B. C. Barton. 2014. Outbreaks attributed to cheese: Differences between outbreaks caused by unpasteurized and pasteurized dairy products, United States, 1998-2011. Foodborne Pathog. Dis. 11:545-551.

Grispoldi, L., L. Massetti, P. Sechi, M. F. Iulietto, M. Ceccarelli, M. Karama, P. A. Popescu, F. Pandolfi, and B. T. Cenci-Goga. 2019. Short communication: Characterization of enterotoxin-producing
Staphylococcus aureus isolated from mastitic cows. J. Dairy Sci. 102:1059-1065.

Hudson, J. A., R. J. Lake, M. G. Savill, P. Scholes, and R. E. McCormick. 2001. Rapid detection of Listeria monocytogenes in ham samples using immunomagnetic separation followed by polymerase chain reaction. J. Appl. Microbiol. 90:614-621.

INPI. 2011. IG201001: Indicação Geográfica-Serro. Instituto Nacional da Propriedade Industrial (INPI), Brasília, DF.

IPHAN. 2006. Parecer $n^{\circ}$ 006/2006: Processo $n^{0}$ 01450.012192/200665 referente ao Registro dos Queijos Artesanais de Minas, a ser inscrito no Livro dos Saberes. Instituto do Patrimônio Histórico e Artístico Nacional (IPHAN), Brasília, DF.

ISO. 1999. Microbiology of food and animal feeding stuffs-Horizontal method for the enumeration of coagulase-positive staphylococci (Staphylococcus aureus and other species)-Part 1: Technique using Baird-Parker agar medium. ISO 6888-1. International Organization for Standardization (ISO), Geneva, Switzerland.

ISO. 2017. Microbiology of the food chain-Horizontal method for the detection, enumeration and serotyping of Salmonella-Part 1: Detection of Salmonella spp. Standard 6579. International Organization for Standardization (ISO), Geneva, Switzerland.

Johler, S., P. Giannini, M. Jermini, J. Hummerjohann, A. Baumgartner, and R. Stephan. 2015. Further evidence for staphylococcal food poisoning outbreaks caused by egc-encoded enterotoxins. Toxins (Basel) 7:997-1004.

Johnson, M. E. 2017. A 100-Year Review: Cheese production and quality. J. Dairy Sci. 100:9952-9965.

Marozzi, S., P. De Santis, S. Lovari, R. Condoleo, S. Bilei, R. Marcianò, and Z. Mezher. 2016. Prevalence and molecular characterisation of shiga toxin-producing Escherichia coli in raw milk cheeses from Lazio region, Italy. Ital. J. Food Saf. 5:4566.

Martins, I. M., D. Y. Kabuki, N. T. N. Miya, and J. L. Pereira. 2014 Occurrence and characterization of enterotoxigenic potential of Staphylococcus isolated from dairy products. J. Food Saf. 34:185192

Martins, J. M., É. Galinari, N. J. Pimentel-Filho, J. I. Ribeiro Jr., M. M. Furtado, and C. L. L. F. Ferreira. 2015. Determining the minimum ripening time of artisanal Minas cheese, a traditional Brazilian cheese. Braz. J. Microbiol. 46:219-230.

Melo, J., P. W. Andrew, and M. L. Faleiro. 2015. Listeria monocytogenes in cheese and the dairy environment remains a food safety challenge: The role of stress responses. Food Res. Int. 67:75-90.

Gerais, M. 2002a. Decreto n 42.645, 2002 June 05 - Aprova o Regulamento da Lei $\mathrm{n}^{\mathrm{0}} 14.185$, de 31 janeiro de 2002 , que dispõe sobre o processo de produção de Queijo Minas Artesanal. Minas Gerais, Diário Oficial da União de Minas Gerais, Brazil.

Gerais, M. 2002b. Lei $\mathrm{n}^{\mathrm{Q}}$ 14.185, 2002 January 31 - Dispõe sobre o processo de produção do Queijo Minas Artesanal e dá outras providências. Minas Gerais, Diário Oficial da União de Minas Gerais, Brazil.

Ning, P., K. Guo, L. Xu, R. Xu, C. Zhang, Y. Cheng, H. Cui, W. Liu, Q. Lv, W. Cao, and Y. Zhang. 2012. Short communication: Evaluation of Brucella infection of cows by PCR detection of Brucella DNA in raw milk. J. Dairy Sci. 95:4863-4867.

Novakovic, B., and R. Grujic. 2017. Importance of adequate hand hygiene of food handlers in snails meat processing. J. Hygienic Eng. Design. 21:23-28

Ongör, H., B. Çetinkaya, M. Karahan, and H. Bulut. 2006. Evaluation of immunomagnetic separation-polyÖmerase chain reaction in direct detection of Brucella abortus and Brucella melitensis from cheese samples. Foodborne Pathog. Dis. 3:245-250.

Paneto, B. R., R. P. Schocken-Iturrino, C. Macedo, E. Santo, and J. M. Marin. 2007. Occurrence of toxigenic Escherichia coli in raw milk cheese in Brazil. Arq. Bras. Med. Vet. Zootec. 59:508-512.

Parussolo, L., R. A. P. Sfaciotte, K. A. Dalmina, F. D. Melo, U. M. Costa, and S. M. Ferraz. 2019. Detection of virulence genes and antimicrobial resistance profiles of Escherichia coli isolates from raw milk and artisanal cheese in Southern Brazil. Semin. Cienc. Agric. 40:163-178.

Pelisser, M. R., C. S. Klein, K. R. Ascoli, T. R. Zotti, and A. C. M. Arisi. 2009. Ocurrence of Staphylococcus aureus and multiplex pcr 
detection of classic enterotoxin genes in cheese and meat products. Braz. J. Microbiol. 40:145-148.

Rahimi, E., and F. Alian. 2013. Presence of enterotoxigenic Staphylococcus aureus in cow, camel, sheep, goat, and buffalo bulk tank milk. Vet. Arh. 83:23-30.

Rodríguez, A., R. Gordillo, M. J. Andrade, J. J. Córdoba, and M. Rodríguez. 2016. Development of an efficient real-time PCR assay to quantify enterotoxin-producing staphylococci in meat products. Food Control 60:302-308.

Rola, J. G., A. Czubkowska, W. Korpysa-Dzirba, and J. Osek. 2016. Occurrence of Staphylococcus aureus on farms with small scale production of raw milk cheeses in Poland. Toxins (Basel) 8:62.

Rosec, J. P., and O. Gigaud. 2002. Staphylococcal enterotoxin genes of classical and new types detected by PCR in France. Int. J. Food Microbiol. 77:61-70.

Silva, J., C. M. Moraes, C. L. Silva, G. A. Sales, L. B. Keid, P. C. M. Matos, A. P. S. S. Lara, and C. C. G. Moraes. 2016. Brucella abortus detected in cheese from the Amazon region: differentiation of a vaccine strain (B19) from the field strain in the states of Pará Amapá and Rondônia, Brazil. Pesqui. Vet. Bras. 36:705-710.

Silva, M. R., A. A. S. Duch, R. T. P. A. Lage, L. D. M. Menezes, J. B. Ribeiro, G. N. Souza, P. M. Soares Filho, A. A. Fonseca Jr., L. S. Faria, and R. R. Costa. 2018. Ocorrência de Brucella em queijo Minas artesanal da microrregião do Serro: Um importante problema de saúde pública. Revista Médica de Minas Gerais 28(Suppl 5):e-S280509.

Soares, D. B., G. P. Monteiro, B. B. Fonseca, E. A. Freitas, E. P. Mendonça, R. T. Melo, J. R. Iasbeck, and D. A. Rossi. 2018. Análise sanitária e físico-química e adequação bacteriológica do queijo minas artesanal produzido em duas propriedades. Cienc. Anim. Bras. 19:e36499.

Swamy, S. C., H. M. Barnhart, M. D. Lee, and D. W. Dreesen. 1996 Virulence determinants invA and $s p v C$ in salmonellae isolated from poultry products, wastewater, and human sources. Appl. Environ. Microbiol. 62:3768-3771.
Toma, C., Y. Lu, N. Higa, N. Nakasone, I. Chinen, A. Baschkier, M. Rivas, and M. Iwanaga. 2003. Multiplex PCR assay for identification of human diarrheagenic Escherichia coli. J. Clin. Microbiol. 41:2669-2671.

Torres-Vitela, M. R., M. Mendoza-Bernardo, J. Castro-Rosas, C. A. Gomez-Aldapa, L. E. Garay-Martinez, V. Navarro-Hidalgo, and A. Villarruel-López. 2012. Incidence of Salmonella, Listeria monocytogenes, Escherichia coli O157:H7, and staphylococcal enterotoxin in two types of Mexican fresh cheeses. J. Food Prot. 75:79-84.

Vale, R. C., M. P. J. Rodrigues, and J. M. Martins. 2018. Influence of the type of ferment in the physicochemical characteristics of cheese Minas artisanal do Serro - Minas Gerais, matured in controlled conditions. Rev. Instituto de Laticinios Candido Tostes 73:82-90.

Viana, F. R., A. L. Oliveira, L. S. Carmo, and C. A. Rosa. 2009 Occurrence of coagulase-positive staphylococci, microbial indicators and physical-chemical characteristics of traditional semihard cheese produced in Brazil. Int. J. Dairy Technol. 62:372-377.

Vinha, M. B., C. L. O. Pinto, and J. B. P. Chaves. 2018. Estafilococos coagulase positiva em queijos Minas Frescal produzidos em agroindústrias familiares. Rev. Instituto de Laticinios Candido Tostes 73:62-72.

Wehr, H. M., and J. F. Frank. 2004. Standard Methods for the Examination of Dairy Products. American Public Health Association, Washington, DC.

\section{ORCIDS}

T. T. Almeida @ https://orcid.org/0000-0002-3717-2143

A. F. Carvalho $\odot$ https://orcid.org/0000-0002-3238-936X

R. S. Yamatogi $\odot$ https://orcid.org/0000-0002-0068-4217

L. A. Nero @ https://orcid.org/0000-0002-4954-5824 